FACTA UNIVERSITATIS

Series: Physical Education and Sport, Vol. 16, No 2, 2018, pp. 451 - 462

https://doi.org/10.22190/FUPES180114040O

Research article

\title{
EFFECTS OF RESISTANCE TRAINING COMBINED WITH WHEY PROTEIN AND CARBOHYDRATES SUPPLEMENTATION ON BODY COMPOSITION AND STRENGTH IN YOUNG ADULT MEN
}

UDC 796.015.52>613.2-053.6

\section{Jelena Obradović1, Mila Vukadinović Jurišić1, Dušan Rakonjac', Aleksandra Aleksić-Veljković², Maja Batez ${ }^{1}$}

${ }^{1}$ Faculty of Sport and Physical Education, University of Novi Sad, Novi Sad, Serbia ${ }^{2}$ Faculty of Sport and Physical Education, University of Niš, Niš, Serbia

\begin{abstract}
The purpose of this study was to determine the effects of whey protein vs carbohydrate supplementation during eight weeks of resistance training on body composition and strength in young adult men. Fifteen young adult men (age 21 5 years; body height: $178.63 \pm 4.1 \mathrm{~cm}$; body mass $81.73 \pm 4.97 \mathrm{~kg}$ ) were randomly assigned to three groups: a whey protein group (WP; $1 \mathrm{~g} / \mathrm{kg}$ immediately after resistance training, $n=5)$, a carbohydrates group (CHO; $30 \mathrm{~g}$ during and $30 \mathrm{~g}$ immediately after resistance training, $n=5)$ or a control group $(K ; n=5)$ for 8 weeks of resistance training. All the participants were tested for each of the following body composition parameters: body mass (BM), fat free mass (FFM), fat mass $(F M)$, glycogen mass $(G M)$, muscle mass $(M M)$, total body water (TBW), extracellular water $(E W)$, intracellular water $(I W)$. Also, the participants were assessed for muscle strength 1RM bench press, IRM squat, IRM shoulder press and maximum pull-ups. Data were analyzed with a two-way mixed model ANOVA $(p<0.05)$. The results indicated that the WP group decreased $F M$, increased $M M$ and had greater results for the $1 R M$ squat than the CHO and $K$ group ( $p<0.05)$. The CHO group improved their results for the IRM bench press, IRM squat and 1RM seated barbell press behind the neck and decreased FM more than the $K$ group ( $p<0.05)$. In conclusion, young adult men who consumed whey protein during 8 weeks of resistance training achieved greater effects on body composition and strength than adult men who consumed carbohydrates supplementation during 8 weeks of resistance training or young adult men who trained 8 weeks without supplementation.
\end{abstract}

Key words: sport nutrition, ergogenic acid, weight training

Received January 14, 2018 / Accepted September 26, 2018

Corresponding author: Jelena Obradović

University of Novi Sad, Faculty of Sport and Physical Education, Lovćenska 16, 21000 Novi Sad, Serbia

Phone: +38121450188•E-mail: jdobradovic@ sbb.rs 


\section{INTRODUCTION}

Resistance training is a modality of exercise that has grown in popularity over the past two decades, particularly for its role in improving athletic performance by increasing muscle strength, power and speed, hypertrophy, local muscular endurance, motor performance, balance and coordination (Kreamer et al., 2000). Training, especially in youths, must be done in a safe environment, and it must be properly designed and under the close supervision of a qualified practitioner (Ignjatović, Stanković, Radovanović, Marković, \& Cvećka, 2009). Although resistance training is beneficial in gaining strength and improvement body composition, people around the world spend millions of dollars on supplementation to improve the effects of resistance training (Schumacher, Schmid, König, \& Berg, 2002). Improving athletic performance, reducing fatigue, changes in body composition and fitness are the increased requirements for the consumption of nutrient supplements (Nemet, Wolach, \& Eliakim, 2005). Protein is one of the most popular dietary supplements marketed to athletes and physically active individuals (Williams, 2005); however, we should not ignore the popularity of carbohydrates. Oral supplementation with protein or essential amino acid immediately before and/or after resistance training is shown to promote a better anabolic response compared with placebo treatments (Tipton et al., 2004). In young adults, the presence of carbohydrates seems to enhance this response (Miller, Tipton, Chinkes, Wolf, \& Wolfe, 2003). Whey protein is considered a high-quality protein fraction because it contains an abundance of essential amino acids, which are necessary for stimulating protein synthesis and supporting muscle growth (Borsheim, Aarsland, \& Wolfe, 2004; Rennie, Wackerhage, Spangenburg, \& Booth, 2004; Hulmi, Lockwood, \& Stout, 2010). Also, whey protein possesses functional properties that promote fat mass reduction and lean mass preservation, including increased fat oxidation (Dougkas, Reynolds, Givens, Elwood, \& Minihane, 2011). Carbohydrate supplementation is an ergogenic aid which may attenuate loss of muscle glycogen associated with resistance training (Haff, Lehmkuhl, McCoy, \& Stone, 2003) and therefore influences the reduction of performance. Consuming carbohydrate supplements before and after resistance training enhances muscle glycogen and achieves a large production of energy during weight training which increases working capacity during exercise (Haff et al., 2003). It also promotes more efficient recovery between sets, improves muscles strength and hypertrophy (Cribb \& Hayes, 2006). Cribb and Hayes (2006) suggest that carbohydrate supplementation during resistance training can maintain muscle glycogen stores. Several studies argue that protein ingestion before and immediately after resistance training is a potent stimulus for muscle size and performance gains compared with carbohydrate only supplements in young (19-23 years old) previously trained (Hoffman, Ratamess, Kango, Falvo, \& Faignbaum, 2007; Cermak, Res, de Groot, Saris, \& Loon, 2012) or untrained individuals (Willoughby, Stout, \& Wilborn, 2007). Ballard, Specker, Binkley, \& Vukovich (2006) examined the differences between the effects of whey protein and casein versus carbohydrates in fifty-two healthy males and females ages 18-25 year during 24 weeks of resistance training. Results showed that fat free mass increased significantly in participants who consumed the whey protein and casein during resistance training than participants who consume carbohydrates (Ballard et al., 2006). However, another study (Baer et al., 2011) showed similar results but on overweight and obese adults. Compared to carbohydrates, whey protein and peptides 
decrease body weight and fat mass after 12 weeks of resistance training (Frestedt, Zenk, Kuskowski, Ward, \& Bastian, 2008). In regard to strength (1RM bench press, 1RM squat), it can be seen that participants who consumed protein (simply milk after training) with resistance training achieved more progress than the group that drank carbohydrates (Josse, Tang, Tarnapolsky, \& Phillips, 2009). A recent investigation (Arazi, Hakimi, \& Hosseini, 2011) also reported greater increase in 1RM squat and 1RM bench press after 8 weeks of resistance training combined with whey protein $(1.8 \mathrm{~g} / \mathrm{kg} /$ day $)$ than carbohydrates. Coburn et al. (2006) has reported that, consumed for 8 weeks ( 3 days per week), $20 \mathrm{~g}$ whey protein and $6.2 \mathrm{~g}$ leucin combined with resistance training elicited greater strength gains than carbohydrates (26.2g multidextrin). During recent years, the popular carbohydrate supplementation is Vitargo®. Vitargo® is a high-molecular weight, starch-based carbohydrate that has shown to leave the stomach faster as well as replenish muscle glycogen more rapidly as compared to lower-molecular weight (Leiper, Aulin, \& Soderlund, 2000). This leads to greater work-output during a 15-minute time-trial 2 hours following cycling to exhaustion when compared to maltodextrin (a low-molecular weight carbohydrate) (Stephens, Roig, Armstrong, \& Greenhaff, 2008). Though Vitargo® replenishes muscle glycogen faster than maltodextrin, there is little research documentation regarding this carbohydrate. In scientific literature, there is a small number of studies investigating the effects of carbohydrate supplements and whey protein on body composition and strength. Therefore, the aim of this study was to determine the effects of different supplementations (carbohydrate and whey protein) during 8 weeks of resistance training on body composition and muscular performance.

\section{METHODS}

\section{Participants}

A total of 15 young adult men aged $22 \pm 6$ years voluntarily participated in this study. To qualify as participants, the men had been training consistently (i.e., 3-5 days per week) for the previous six months; submitted a detailed description of their current training program; had not ingested any ergogenic supplement for 12 weeks prior to the start of supplementation, and agreed not to ingest any other nutritional supplements, or nonprescription drugs that may affect muscle growth or the ability to train intensely during the study. Fifteen participants completed the study after being randomly assigned to one of three groups. One group consumed whey protein during 8 weeks of resistance training $(1 \mathrm{~g} / \mathrm{kg})(\mathrm{WP} ; \mathrm{n}=5)$; a second group consumed carbohydrate supplementation $(30 \mathrm{~g}$ during the training session and $30 \mathrm{~g}$ immediately after the training session or $502.4 \mathrm{kcal}$ ) during 8 weeks of resistance training $(\mathrm{CHO} ; n=5)$. And a third group only took part in 8 weeks of resistance training, without supplementation $(\mathrm{K} ; \mathrm{n}=5)$. All groups performed the same resistance training for 4 days per week via a split routine program for 8 weeks (Table 3). The characteristics of the young adult men are presented in Table 1. The study was approved by the Research Ethics Committee of the Faculty of Sport and Physical Education at the University of Novi Sad, according to the Helsinki Declaration. 
Table 1 Baseline anthropometric characteristics of the participants;

Values are means $( \pm \mathrm{SD})$

\begin{tabular}{lccc}
\hline & $\mathrm{WP}(\mathrm{n}=5)$ & $\mathrm{CHO}(\mathrm{n}=5)$ & $\mathrm{K}(\mathrm{n}=5)$ \\
\hline Age (years) & $22 \pm 6$ & $20 \pm 4$ & $21 \pm 4$ \\
Body height $(\mathrm{cm})$ & $178.6 \pm 4.2$ & $179.3 \pm 6.0$ & $178 \pm 2.1$ \\
Body mass $(\mathrm{kg})$ & $80.3 \pm 4.42$ & $83.50 \pm 8.37$ & $81.38 \pm 2.12$ \\
\hline
\end{tabular}

Macronutrient intake was followed during the 12-week training sessions (Table 2).

Table 2 Mean $( \pm \mathrm{SD})$ daily macronutrient intake of the $\mathrm{CHO}$, WP and $\mathrm{K}$ groups during 12-week training sessions

\begin{tabular}{ccccc}
\hline Group & $\begin{array}{c}\text { Carbohydrate } \\
\text { (Kcal) }\end{array}$ & $\begin{array}{c}\text { Carbohydrate } \% \\
\text { (g/day) }\end{array}$ & $\begin{array}{c}\text { Protein\% } \\
\text { (g/day) }\end{array}$ & $\begin{array}{c}\text { Fat \% } \\
(\mathrm{g} / \text { day })\end{array}$ \\
\hline WP & $2846.53 \pm 187.94$ & $57.95 \pm 8.94$ & $24.47 \pm 3.30$ & $16.77 \pm 5.02$ \\
CHO & $2858.00 \pm 211.03$ & $58.67 \pm 8.43$ & $23.99 \pm 2.22$ & $17.22 \pm 6.61$ \\
K & $2843.40 \pm 239.01$ & $58.07 \pm 3.98$ & $24.38 \pm 0.71$ & $16.48 \pm 5.38$ \\
\hline
\end{tabular}

*Average daily macronutrient intake is based on 7-day food records collected the week prior to training and supplementation and over the course of 12 weeks. No significant differences in macronutrient intake were observed between the WP, CHO and K groups throughout the course of the study ( $>>0.05)$

\section{Procedures}

All participants, regardless of group assignment, were tested for each of the following body composition parameters: body mass, body height, fat-free mass, fat mass, glycogen mass, muscle mass, total body water, extracellular water and intracellular water. Also, participants' strength was measured: 1RM (one-repetition maximum) bench press, 1RM squat, 1RM seated barbell press behind the neck and maximal pull-ups. Measuring body composition and strength was executed in the laboratory of the Faculty of Sport and Physical Education in Novi Sad two times [prior to (after a familiarization period) and after completion of the training program (after 8 weeks of resistance training)] at the same time (from $8 \mathrm{~h}$ to $12 \mathrm{~h}$ ).

\section{Body composition testing}

Body height $(\mathrm{BH})$ was measured to the nearest $0.1 \mathrm{~cm}$ using a Martin anthropometer (GPM in Switzerland), while body mass (BM) was measured on a calibrated beam balance platform scale to the nearest $0.1 \mathrm{~kg}$. To assess the body composition parameters of the participants, the bio impedance Maltron Bioscan 920 - 2 (BioScan 920-2, Maltron International Ltd) was used. The Bioimpedance Maltron Bioscan 920-2 method estimates the structure of the body composition by transmitting a low, safe dose of current $(800 \mu \mathrm{amp}$ at $50 \mathrm{kHz})$ through a human body. The following parameters of the body composition were measured: fat free mass (FFM), fat mass (FM), glycogen mass (GM), muscle mass (MM), total body water (TBW), extracellular water (EW) and intracellular water (IW).

\section{Muscle strength testing}

During each testing session, participants performed one-repetition-maximum (1RM) strength test for the bench press, squat, behind the neck shoulder press and maximum pull-ups. 
1RM bench press - The 1 RM test on the bench press was conducted and described by Hoffman, Ratamess, Kang, Falvo, \& Faigenbaum (2006). Each participant performed a warm up set using resistance that was approximately $40-60 \%$ of his perceived maximum and then performed three or four subsequent attempts to determine the 1RM. Rests between lifts lasted between $3-5$ minutes. Bench-press testing was performed in the standard supine position. The participants lowered the Olympic weight lifting bar to mid-chest level and then pressed the weight until their elbows were fully extended.

1RM squat - The squat exercise required the participants to rest an Olympic weight lifting bar across the trapezius at a self-chosen location. The squat was performed in a parallel position (closely monitored by research staff) which was achieved when the greater trochanter of the femur was lowered to the same level as the knee. The participants then lifted the weight until their knees were extended (Hoffman et al., 2009).

1RM shoulder press - Each participant performed a warm-up set using resistance that was approximately $40-60 \%$ of his perceived maximum and then performed three or four subsequent attempts to determine the 1RM. The rest between lifts was $3-5$ minutes. The seated barbell press behind the neck testing was performed in the standard seated position. The participants pressed the barbell with weight until their elbows were fully extended.

Pull-ups (maximum number) - Participants completed the maximum number of pronated pull-ups possible in one minute (Chen et al., 2007). They were positioned hanging from a bar with arms at full extension then pulled up so their chin reached the top of the bar then lowered themselves back down to full arm extension with their legs also fully extended (Grant et al., 2001). If they used any momentum from their lower body as assistance the repetition was not counted. They were able to rest with arms at full extension, but if they let go of the bar the test was terminated.

\section{Training program}

Participants trained for 12 weeks (four sessions per week). All participants underwent a familiarization period before starting the resistance training protocol.

Familiarization period - The first phase of the training procedure was a four-week preparatory resistance training period, during which the participants were familiarized with resistance training. Over the course of this resistance training period, the participants performed a whole body workout, 2-3 sets of every exercise, with 10-12 repetitions in every set. Recovery time between the sets lasted two minutes. Training loads were $60-80 \%$ of one repetition maximum (1RM) increasing throughout the preparatory phase. The purpose of this familiarization period was to prepare the participants for resistance training and improve improper technique.

Resistance training - After familiarization, the participants were involved in an eightweek resistance (four times per week) training protocol. The method used is submaximal load up to muscle failure. The load ranged from $80-95 \%$ of maximum, the number of sets was 3-4, the number of exercises 6 , the number of repetitions $10-12$, resting between repetitions of the series 2-3 minutes, between exercises 4-5 minutes. There were three different training sessions, the fourth session was the same as the first, the fifth as the second etc. The raining program was described by Maksimović, Vukadinović, Rakonjac, Obradović, \& Barišić (2016). Qualified staff attended the training sessions and monitored the work of the participants (Table 3 ). 
Table 3 Eight-week resistance training program

\begin{tabular}{|c|c|c|c|c|c|c|}
\hline First training & $\begin{array}{l}\text { Primary } \\
\text { exercises }\end{array}$ & No. & Load & $\begin{array}{l}\text { Secondary } \\
\text { exercises }\end{array}$ & No. & Load \\
\hline Chest & Bench press & 4 & $\begin{array}{l}1-80 \% 1 \mathrm{RM} \\
2-90 \% 1 \mathrm{RM} \\
3-95 \% 1 \mathrm{RM} \\
4-80 \% 1 \mathrm{RM}\end{array}$ & $\begin{array}{l}\text { Incline dumbbell flies } \\
\text { Pull over }\end{array}$ & 3 & $\begin{array}{l}1-80 \% 1 \mathrm{RM} \\
2-90 \% 1 \mathrm{RM} \\
3-95 \% 1 \mathrm{RM}\end{array}$ \\
\hline Biceps & $\begin{array}{l}\text { Scott bench } \\
\text { biceps curls }\end{array}$ & 4 & $\begin{array}{l}1-80 \% 1 \mathrm{RM} \\
2-90 \% 1 \mathrm{RM} \\
3-95 \% 1 \mathrm{RM} \\
4-80 \% 1 \mathrm{RM} \\
\end{array}$ & $\begin{array}{l}\text { Seated dumbbell } \\
\text { biceps curls } \\
\text { Single-arm preacher } \\
\text { curls }\end{array}$ & 3 & $\begin{array}{l}1-80 \% 1 \mathrm{RM} \\
2-90 \% 1 \mathrm{RM} \\
3-95 \% 1 \mathrm{RM}\end{array}$ \\
\hline Second training & & & & & & \\
\hline Back & Pull-ups & 4 & $\begin{array}{l}1-80 \% 1 \mathrm{RM} \\
2-90 \% 1 \mathrm{RM} \\
3-95 \% 1 \mathrm{RM} \\
4-80 \% 1 \mathrm{RM}\end{array}$ & $\begin{array}{l}\text { Deadlift } \\
\text { Seated row }\end{array}$ & 3 & $\begin{array}{l}1-80 \% 1 \mathrm{RM} \\
2-90 \% 1 \mathrm{RM} \\
3-95 \% 1 \mathrm{RM}\end{array}$ \\
\hline Triceps & $\begin{array}{l}\text { Barbell } \\
\text { lying triceps } \\
\text { extensions }\end{array}$ & 4 & $\begin{array}{l}1-80 \% 1 \mathrm{RM} \\
2-90 \% 1 \mathrm{RM} \\
3-95 \% 1 \mathrm{RM} \\
4-80 \% 1 \mathrm{RM}\end{array}$ & $\begin{array}{l}\text { Triceps push-downs } \\
\text { One-arm triceps } \\
\text { dumbbell extensions }\end{array}$ & 3 & $\begin{array}{l}1-80 \% 1 \mathrm{RM} \\
2-90 \% 1 \mathrm{RM} \\
3-95 \% 1 \mathrm{RM}\end{array}$ \\
\hline \multicolumn{7}{|l|}{ Third training } \\
\hline Shoulder & $\begin{array}{l}\text { Seated } \\
\text { barbell } \\
\text { shoulder } \\
\text { press }\end{array}$ & 4 & $\begin{array}{l}1-80 \% 1 \mathrm{RM} \\
2-90 \% 1 \mathrm{RM} \\
3-95 \% 1 \mathrm{RM} \\
4-80 \% 1 \mathrm{RM}\end{array}$ & $\begin{array}{l}\text { High pull } \\
\text { Dumbbell shoulder } \\
\text { press }\end{array}$ & 3 & $\begin{array}{l}1-80 \% 1 \mathrm{RM} \\
2-90 \% 1 \mathrm{RM} \\
3-95 \% 1 \mathrm{RM}\end{array}$ \\
\hline Legs & Squat & 4 & $\begin{array}{l}1-80 \% 1 \mathrm{RM} \\
2-90 \% 1 \mathrm{RM} \\
3-95 \% 1 \mathrm{RM} \\
4-80 \% 1 \mathrm{RM}\end{array}$ & $\begin{array}{l}\text { Leg curls } \\
\text { Dumbbell lunge }\end{array}$ & 3 & $\begin{array}{l}1-80 \% 1 \mathrm{RM} \\
2-90 \% 1 \mathrm{RM} \\
3-95 \% 1 \mathrm{RM}\end{array}$ \\
\hline
\end{tabular}

\section{Supplementation}

During the familiarization period (4 weeks) the participants $(n=15)$ did not consume supplements. After the period of familiarization, the participants consumed supplementation as a drink during the training protocol ( 8 weeks) 4 days per week while maintaining their habitual daily diet.

WP group - 100\% fuel whey protein (Twinlab) - Participants in the WP group used $1 \mathrm{~g} / \mathrm{kg}$ Fuel Twinlab $100 \%$ whey protein immediately after resistance training. One scoop of $35 \mathrm{~g}$ (140kcal) comprises $25 \mathrm{~g}$ of whey protein (whey isolate and whey concentrate), $2 \mathrm{~g}$ fat, $5 \mathrm{~g}$ carbohydrates, $3 \mathrm{~g}$ BCAA (L-alanine 1290mg, L-arginine $600 \mathrm{mg}$ L-aspartic 3320mg, 730mg Cysteine, Glutamic acid 4460mg, Glycine $460 \mathrm{mg}$, 470mg L-histidine, L-isoleucine, 1620mg, 2660mg L-leucine, L-lysine 2190mg, L-methionine 620mg, 840 mg L-phenylalanine, L-proline, 1660mg, 1290mg L-serine, L-threonine 1810mg, Ltiptofan 560mg, 770mg L-tyrosine, L-valine 1480mg).

CHO group - Vitargo ${ }^{\circledR}$ Carbohydrate (Scitec Nutrition) - Participants in the CHO group consumed $30 \mathrm{~g}(502.4 \mathrm{kcal})$ (Vitargo ${ }^{\circledR}$ Scitec Nutrition) during and $30 \mathrm{~g}$ immediately after resistance training, one spoonful or $30 \mathrm{~g}(502,4 \mathrm{kcal})$ of carbohydrates with molecular weight from barley starch. 


\section{Statistical analysis}

Descriptive data were calculated for all the variables. Group differences at baseline and for dietary intake evaluated using the analysis of variance (ANOVA) method. Normality assumptions for all data before and after the intervention were checked respectively with the Kolmogorov-Smirnov test. A 3x2 mixed design factorial ANOVA was used to test for interaction and main effect for time (initial vs final) and group (WP, $\mathrm{CHO}, \mathrm{K}$ ) on dependent body composition and strength variable. Cohen d effect sizes (ES) were also calculated to determine the magnitude of the group differences in body composition and strength. ES was classified as follows: $<0.2$ was defined as trivial; $0.2-$ 0.6 was defined as small; 0.6-1.2 was defined as moderate; 1.2-2.0 was defined as a large; $>2.0$ was defined as very large; and > 4.0 was defined as extremely large (Hopkins, Marshall, Batterham, \& Hanin, 2009). Statistical analyses were conducted in the Statistical Package for the Social Sciences (v20.0, SPSS, Inc., Chicago, IL, USA).

\section{RESULTS}

The Kolmogorov-Smirnov test has shown that data were normally distributed. An ANOVA reveled no statistically significant differences between the groups for all variables prior to the training. Compared with pre-training, there was a significant $(p<0.05)$ improvement in BM, FFM, FM and MM in all three groups (Table 4). However, the WP group in FM and MM achieved significantly greater gains compared to the $\mathrm{CHO}$ and $\mathrm{K}$ groups $(\mathrm{p}<0.05)$. CHO group achieved a higher FM reduction than in $\mathrm{K}$ group $(\mathrm{p}<0.05)$. In the WP, CHO i K groups, there were no significant changes in TBW, EW and IW.

Table 4 Mean $( \pm S D)$ results of different parameters for body composition before the experimental period (initial) and after the 8-week experimental period (final)

\begin{tabular}{|c|c|c|c|c|c|c|c|c|c|c|c|c|}
\hline & & $\sqrt{\mathrm{P}}$ group $(\mathrm{n}=$ & & & & $\mathrm{O}$ group & $\mathrm{n=5)}$ & & & group (1 & $=5)$ & \\
\hline & Initial & Final & $\Delta(\%)$ & $\mathrm{ES}$ & Initial & Final & $\Delta(\%)$ & $\mathrm{ES}$ & Initial & Final & $\Delta(\%)$ & $\mathrm{ES}$ \\
\hline $\begin{array}{l}\mathrm{BM} \\
(\mathrm{kg})\end{array}$ & $\begin{array}{l}80.30 \\
(4.25)\end{array}$ & $\begin{array}{c}84.94 \\
(1.34) \dagger\end{array}$ & 5.8 & 1.47 & $\begin{array}{l}83.50 \\
(8.37)\end{array}$ & $\begin{array}{c}85.09 \\
(7.57) \dagger\end{array}$ & 1.9 & 0.19 & $\begin{array}{l}81.38 \\
(2.12)\end{array}$ & $\begin{array}{l}81.82 \\
(4.08)\end{array}$ & 0.5 & 0.13 \\
\hline $\begin{array}{l}\text { FFM } \\
(\mathrm{kg})\end{array}$ & $\begin{array}{l}68.86 \\
(2.81)\end{array}$ & $\begin{array}{c}75.12 \\
(6.25) \dagger\end{array}$ & 9.1 & 1.29 & $\begin{array}{l}71.29 \\
(7.97)\end{array}$ & $\begin{array}{c}75.51 \\
(6.48) \dagger\end{array}$ & 5.9 & 0.58 & $\begin{array}{l}69.62 \\
(2.97)\end{array}$ & $\begin{array}{l}70.58 \\
(2.09)\end{array}$ & 1.4 & 0.37 \\
\hline $\begin{array}{l}\text { FM } \\
(\mathrm{kg})\end{array}$ & $\begin{array}{c}8.72 \\
(0.57)\end{array}$ & $\begin{array}{c}6.94 \\
(0.36) \dagger \bullet *\end{array}$ & 25.6 & 3.73 & $\begin{array}{c}8.83 \\
(0.51)\end{array}$ & $\begin{array}{c}7.65 \\
(0,48) \dagger+\end{array}$ & 15.4 & 2.38 & $\begin{array}{c}8.30 \\
(0.44)\end{array}$ & $\begin{array}{c}7.90 \\
(0.44) \dagger\end{array}$ & 5.0 & 0.90 \\
\hline $\begin{array}{l}\text { GM } \\
(\mathrm{kg})\end{array}$ & $\begin{array}{c}613.80 \\
(22.1)\end{array}$ & $\begin{array}{l}620.40 \\
(27.97)\end{array}$ & 0.0 & 0.26 & $\begin{array}{c}678.60 \\
(65.2)\end{array}$ & $\begin{array}{c}679.00 \\
(59.2)\end{array}$ & 0.0 & 0.01 & $\begin{array}{l}619.60 \\
(24.6)\end{array}$ & $\begin{array}{c}619.62 \\
(26.0)\end{array}$ & 0.0 & 0.00 \\
\hline $\begin{array}{l}\mathrm{MM} \\
(\mathrm{kg})\end{array}$ & $\begin{array}{l}33.51 \\
(1.49)\end{array}$ & $\begin{array}{c}37.63 \\
(1.18) \dagger \bullet *\end{array}$ & 12.3 & 3.06 & $\begin{array}{l}33.90 \\
(2.19)\end{array}$ & $\begin{array}{c}35.32 \\
(1.71) \dagger\end{array}$ & 4.2 & 0.72 & $\begin{array}{l}31.98 \\
(1.52)\end{array}$ & $\begin{array}{c}33.27 \\
(0.88) \dagger\end{array}$ & 4.0 & 1.03 \\
\hline $\begin{array}{l}\text { TBW } \\
(\mathrm{kg})\end{array}$ & $\begin{array}{l}62.05 \\
(3.08)\end{array}$ & $\begin{array}{l}61.80 \\
(2.19)\end{array}$ & 0.4 & 0.09 & $\begin{array}{l}60.24 \\
(2.68)\end{array}$ & $\begin{array}{l}60.65 \\
(2.42)\end{array}$ & 0.6 & 0.16 & $\begin{array}{l}61.35 \\
(2.21)\end{array}$ & $\begin{array}{l}60.91 \\
(2.58)\end{array}$ & 0.0 & 0.18 \\
\hline $\begin{array}{l}\text { EW } \\
(\mathrm{kg})\end{array}$ & $\begin{array}{l}41.93 \\
(0.86)\end{array}$ & $\begin{array}{l}43.03 \\
(0.69)\end{array}$ & 2.6 & 1.41 & $\begin{array}{l}42.60 \\
(2.37)\end{array}$ & $\begin{array}{l}42.76 \\
(1.45)\end{array}$ & 0.4 & 0.08 & $\begin{array}{l}40.82 \\
(1.38)\end{array}$ & $\begin{array}{l}41.90 \\
(0.91)\end{array}$ & 2.6 & 0.92 \\
\hline $\begin{array}{l}\text { IW } \\
(\mathrm{kg})\end{array}$ & $\begin{array}{l}58.03 \\
(0.82)\end{array}$ & $\begin{array}{l}56.95 \\
(0.69)\end{array}$ & 1.9 & 1.42 & $\begin{array}{l}57.39 \\
(2.37)\end{array}$ & $\begin{array}{l}57.22 \\
(1.45)\end{array}$ & 0.3 & 0.08 & $\begin{array}{l}56.56 \\
(3.11)\end{array}$ & $\begin{array}{l}56.59 \\
(0.84)\end{array}$ & 0.0 & 0.01 \\
\hline
\end{tabular}

Legend: $\Delta(\%)$-percent changes between initial and final; ES-effect size; $\uparrow$ significant difference from initial; + significant difference between $\mathrm{CHO}$ and $\mathrm{K}$ groups $(\mathrm{p}<0.05)$; * significant difference between WP and $\mathrm{K}$ groups $(\mathrm{p}<0.05) ; \bullet$ significant difference between WP and CHO groups $(\mathrm{p}<0.05)$. 
There were significant differences $(\mathrm{p}<0.05)$ between the initial and final testing for all the strength variables in all groups. In the 1RM squat, the ANOVA revealed a statistically significant difference between groups pre- to post-training $(\mathrm{p}<0.05)$. However, the WP group made significantly greater gains in 1RM squat compared to $\mathrm{CHO}$ and $\mathrm{K}$ groups $(\mathrm{p}<0.05)$. The $\mathrm{CHO}$ group achieved significantly greater gains for the 1RM bench press, 1RM squat, 1RM shoulder press compared to the K group.

Table 5 Mean $( \pm \mathrm{SD})$ results of muscle strength for the WP, CHO and $\mathrm{K}$ groups prior (initial) and after the 8-week experimental period (final)

\begin{tabular}{|c|c|c|c|c|c|c|c|c|c|c|c|c|}
\hline & \multicolumn{4}{|c|}{ WP $(n=5)$} & \multicolumn{4}{|c|}{$\mathrm{CHO}(\mathrm{n}=5)$} & \multicolumn{3}{|c|}{$K(n=5)$} & \\
\hline & Initial & Final & $\Delta(\%)$ & ES & Initial & Final & $\Delta(\%)$ & $\mathrm{ES}$ & Initial & Final & $\Delta(\%)$ & ES \\
\hline $\begin{array}{l}1 \mathrm{RM} \\
\text { bench } \\
\text { press }(\mathrm{kg})\end{array}$ & $\begin{array}{c}84.00 \\
(11.93)\end{array}$ & $\begin{array}{c}104.20 \\
(14.70) \dagger^{*}\end{array}$ & 24.04 & 1.51 & $\begin{array}{l}85.00 \\
(5.00)\end{array}$ & $\begin{array}{c}103.00 \\
(8.36) \dagger^{+}\end{array}$ & 21.1 & 2.61 & $\begin{array}{l}82.00 \\
(7.58)\end{array}$ & $\begin{array}{c}90.60 \\
(7.19) \dagger\end{array}$ & 10.4 & 1.16 \\
\hline $\begin{array}{l}1 \mathrm{RM} \\
\text { squat } \\
(\mathrm{kg})\end{array}$ & $\begin{array}{l}95.00 \\
(8.66)\end{array}$ & $\begin{array}{c}113.00 \\
(9.74) \dagger \bullet *\end{array}$ & 18.94 & 1.95 & $\begin{array}{l}92.00 \\
(8.36)\end{array}$ & $\begin{array}{c}101.00 \\
(5.47) \dagger+\end{array}$ & 9.7 & 1.27 & $\begin{array}{l}92.00 \\
(8.36)\end{array}$ & $\begin{array}{c}95.00 \\
(5.00) \dagger\end{array}$ & 0.01 & 0.43 \\
\hline $\begin{array}{l}\text { 1RM } \\
\text { shoulder } \\
\text { press }(\mathrm{kg})\end{array}$ & $\begin{array}{l}57.00 \\
(6.70)\end{array}$ & $\begin{array}{c}78.00 \\
(7.58) \dagger *\end{array}$ & 36.8 & 2.94 & $\begin{array}{c}61.80 \\
(11.00 \\
)\end{array}$ & $\begin{array}{c}84.40 \\
(7.40) \dagger+\end{array}$ & 36.5 & 2.41 & $\begin{array}{c}59.00 \\
(12.44)\end{array}$ & $\begin{array}{c}65.20 \\
(12.00) \dagger\end{array}$ & 1.05 & 0.51 \\
\hline $\begin{array}{l}\text { Pull-ups } \\
(\max )\end{array}$ & $\begin{array}{l}10.60 \\
(0.89)\end{array}$ & $\begin{array}{c}17.20 \\
(3.03) \dagger^{*}\end{array}$ & 62.26 & 2.95 & $\begin{array}{l}10.20 \\
(2.77)\end{array}$ & $\begin{array}{c}15.80 \\
(3.89) \dagger\end{array}$ & 54.90 & 1.66 & $\begin{array}{c}9.40 \\
(1.94)\end{array}$ & $\begin{array}{c}12.00 \\
(1.87) \dagger\end{array}$ & 27.65 & 0.38 \\
\hline
\end{tabular}

Legend: $\Delta(\%)$-percent changes between initial and final measurement; ES-effect size; $\uparrow$ significant difference from initial; + significant difference between $\mathrm{CHO}$ and $\mathrm{K}$ groups $(\mathrm{p}<0.05)$; $*$ significant difference between WP and K groups $(\mathrm{p}<0.05)$; $\bullet$ significant difference between WP and CHO groups $(\mathrm{p}<0.05)$.

\section{DISCUSSION}

The purpose of this study was to examine the effects of different supplements with resistance training on body composition and strength of physically active young adult males. The primary findings of this study was that supplementations (whey protein and carbohydrates) with resistance training caused improvements in body composition and strength.

The results of the present study indicate resistance training in combination with whey protein supplementation $(1 \mathrm{~g} / \mathrm{kg}$ ) lead to greater improvement in body composition (fat mass and muscle mass) and strength (1RM squat) than carbohydrates and the control group, while participants who consumed carbohydrates achieved better results in body composition (fat mass) and strength (1RM bench press, 1RM squat, 1RM shoulder) than the control group. Significant decreases were observed for WP group in FM for 25.6\%; $\mathrm{ES}=3.73$ compared to $\mathrm{CHO}$ 15.4\%; $\mathrm{ES}=2.38$ and $\mathrm{K} \mathrm{5 \%}$; $\mathrm{ES}=0.09$ (p<0.05). The results are in agreement with Baer et al. (2011), who showed that 23 weeks of resistance training with whey protein supplementation (56g/day) achieved a greater reduction in FM (up to $1.8 \mathrm{~kg}$ ) than the group who drank carbohydrate supplementation. One main reason for the advantage of the WP group over the $\mathrm{CHO}$ in decreased FM could be that ingesting protein immediately after resistance training increases the flow and absorption of amino acids in skeletal muscles (Tipton et al., 2001) which increases muscle protein synthesis (Hulmi et al., 2010) and has a positive effect on the increase of MM and reduction in FM. 
Colker, Swain, Fabrucini, Shi, \& Kaiman (2000) found that the consumption of whey protein (whey protein $40 \mathrm{~g} / \mathrm{d}$ with $5 \mathrm{~g}$ l-glutamine and $3 \mathrm{~g}$ of branched-chain amino acids (leucine, isoleucine and valine)) combined with a 10 -week resistance training exhibited a trend toward gaining FFM (1.6kg). Willoughby et al. (2007) stated that there was a reduction in FM and increase in FFM $(+5.62 \pm 0.98 \mathrm{~kg})$, primarily as a result of ingesting protein supplementation than ingesting carbohydrates. However, results of these studies are in contrast with Hoffman et al. (2009). In that research, there were no significant changes in FM. A possible explanation for this contrast between the results can be observed in participants and supplementation. In the current study, we analyzed participants who are physically active, young adult men without experience in resistance training, and they consumed $100 \%$ fuel whey protein. On the other hand Hoffman et al. (2009) investigated experienced resistance trained athletes (participants who participated in 10 weeks of resistance training) which used whey protein and carbohydrates together (42g mixed protein with $2 \mathrm{~g}$ carbohydrate).

One of the findings from this study was that there was a greater significant improvement in $\mathrm{MM}$ for $12.3 \%$ in the WP group than the $\mathrm{CHO}$ group $4.2 \%$ and $\mathrm{K}$ group $4 \%(\mathrm{p}<0.05)$. Candow, Burke, Smith-Palmer, \& Burke (2006) found significant improvement in MM for $4.7 \%$ after consuming $1.2 \mathrm{~g} / \mathrm{kg}$ whey protein during 6 weeks of resistance training. According to Joy et al. (2013) resistance trained males increased MM by $3.2 \mathrm{~kg}$ after 8 weeks of resistance training and whey protein consumption. However, Vukadinović Jurišić, Rakonjac, \& Obradović (2017) found significant improvement in MM by $9.3 \%$ after consumed carbohydrates during 8 weeks of resistance training. It is known that resistance training causes stimulation of protein synthesis and increased protein degradation (Tipton et al., 2001). However, ingestion of protein or amino acids immediately after resistance training increases synthesis and weak degradation of proteins in muscles (Wolfe, 2001). On the other hand, the ingestion of carbohydrate supplements during and immediately after resistance training increases concentration of insulin in plasma and growth of hormone levels (Conley \& Stone, 1996), but it is not enough to increase muscle synthesis, probably because of the accompanying reduction in the concentration of amino acids (Rasmussen, Tipton, Miller, Wolf, \& Wolfe, 2000). Therefore, protein supplements may be needed in order to maximize protein synthesis as compared to carbohydrates (Rasmussen et al., 2000).

Another finding of the present study was the significantly greater improvement in 1RM squat in WP group (18.94\%; $\mathrm{ES}=1.95)$ than in the $\mathrm{CHO}$ group $(9.7 \%$; $\mathrm{ES}=1.27)$ and $\mathrm{K}$ group $(0.01 \%$; $\mathrm{ES}=0.43)$. The $\mathrm{CHO}$ group achieved greater results in the $1 \mathrm{RM}$ bench press (21.1\%; $\mathrm{ES}=2.21), 1 \mathrm{RM}$ squat $(9.7 \% ; \mathrm{ES}=1.27)$ and the $1 \mathrm{RM}$ shoulder press $(36.5 \%$; $\mathrm{ES}=2.41$ ) than the $\mathrm{K}$ group. The increases observed in our study were in line with another study. Arazi et al. (2011) found similar results after 8 weeks (3 times per week) of resistance training ( 3 sets, 8 reps, and load $80 \%$ 1RM) with whey protein $(1.8 \mathrm{~g} / \mathrm{kg} /$ day $)$ than participants who consumed carbohydrates. The results could be explained by analyzing the effect of whey protein and carbohydrates on the human body. Intake of protein or amino acid immediately after resistance training improves muscle protein synthesis (Moore et al., 2009; Burd, Tang, Moore, \& Philips, 2009) which realizes the acute effects of exercise, thus leading to long hypertrophy. However, consuming carbohydrates before and after resistance training improves muscle glycogen, and it is believed that muscle glycogen has a great contribution to the production of energy during resistance training (Haff et al., 2003), which increases working capacity during exercise. According to this, consumption of carbohydrates 
can improve and develop strength during resistance training (Cribb \& Hayes, 2006) but not to the same extent as whey protein. In other variables (1RM bench press, 1RM shoulder press and max pull ups), our study indicated that there is no statistically significant difference ( $\mathrm{p}>0.05$ ) among the groups (WP vs $\mathrm{CHO}$ ) in young adult men.

\section{CONCLUSION}

In conclusion, this study examined the effects of 8 weeks of resistance training in combination with whey protein or carbohydrate supplementation on body composition and strength. Findings from the present investigation indicate that greater significant improvements in body composition and strength were achieved by young adult men who took part in 8 weeks of resistance training and consumed whey protein $(1 \mathrm{~g} / \mathrm{kg})$ than young adult men who took part in 8 weeks of resistance training and consumed carbohydrate supplementation (30g during and 30g immediately after resistance training). Eight weeks of resistance training in combination with whey protein supplementation (whey protein group) had beneficial effects on muscle mass, fat mass and strength (1RM squat) than carbohydrates on the control group. Carbohydrate supplementation combined with 8 weeks of resistance training (carbohydrate group) had beneficial effects on fat mass, 1RM bench press, 1RM squat and 1RM shoulder press compared to the control group. Future studies should focus on longer training programs, and determine the effects of combining different supplements with resistance training on anthropometry, muscle biopsies, concentrations of serum insulin and other parameters. It would be interesting to examine the effects of supplementation on other types of physical performance and physical health.

\section{REFERENCES}

Arazi, H., Hakimi, M., \& Hoseini, K. (2011). The effects of whey protein supplementation on performance and hormonal adaptations following resistance training in novice men. Baltic Journal of Health and Physical Activity, $3(2), 87-95$.

Baer, D.J., Stote, K.S., Paul, D.R., Harris, K.G., Rumpler, W.V., \& Clevidence, B.A. (2011). Whey protein but not soy protein supplementation alters body weight and composition in free-living overweight and obese adults. Journal of Nutrition, 141(8), 1489-1494.

Ballard, T.L., Speaker, B.L., Binkley, T.L., \& Vukovich, M.D. (2006). Effect of protein supplementation during a 6month strength and conditioning program on areal and volumetric bone parameters. Bone Journal, 38(6), 898-904.

Borsheim, E., Aarsland, A., \& Wolfe, R.R. (2004). Effect of an amino acid, protein, and carbohydrate mixture on net muscle protein balance after resistance exercise. International Journal of Sport Nutrition and Exercise Metabolism, 14(3), 255-271.

Burd, N.A., Tang, J.E., Moore, D.R., \& Phillips, S.M. (2009). Exercise training and protein metabolism: influences of contraction, protein intake, and sex-based differences. Journal of Applied Physiology, 106(5), 1692-1701.

Candow, D.G., Burke, N.C., Smith-Palmer, T., \& Burke, D.G. (2006). Effect of whey and soy protein supplementation combined with resistance training in young adults. International Journal of Sport Nutrition and Exercise Metabolism, 16(3), 233-244.

Cermak, N.M., Res, P.T., de Groot, L.C., Saris, W.H., \& Loon, L.J. (2012). Protein supplementation augments the adaptive response of skeletal muscle to resistance-type exercise training: a meta-analysis. The American Journal of Clinical Nutrition, 96(6), 1454-1465.

Chen, K.W., Chiu, P.K., Lin, I., Xu, K.F., Hsu, M., \& Liang, M.T. (2007). A study of basic military training of the physical fitness and physical self-concept for cadets. Journal of Physical Education \& Recreation, 13(2), 6-12.

Coburn, J.W., Housh, D.J., Housh, T.J., Malek, M.H., Beck, T.W., Cramer, J. T., et al. (2006). Effects of leucine and whey protein supplementation during eight weeks of unilateral resistance training. The Journal of Strength \& Conditioning Research, 20(2), 284-291. 
Conley, M.S. \& Stone, M.H. (1996). Carbohydrate ingestion/supplementation for resistance exercise and training. Sports Medicine, 21(1), 7-17.

Colker, C., Swain, M., Fabrucini, B., Shi, Q., \& Kaiman, D. (2000). Effects of supplemental protein on body composition and muscular strength in healthy athletic male adults. Current Therapeutic Research, 61(1), 19-28.

Cribb, P.J., \& Hayes, A. (2006). Effects of supplement timing and resistance exercise on skeletal muscle hypertrophy. Medicine and Science in Sports and Exercise, 38(11), 1918-1925.

Dougkas, A., Reynolds, C.K., Givens, I.D. Elwood, P.C., \& Minihane, A.M. (2011). Associations between dairy consumption and body weight: a review of the evidence and underlying mechanisms. Nutrition Research Reviews, 24(1), 72-95.

Frestedt, J.L., Zenk, J.L., Kuskowski, M.A., Ward, L.S., \& Bastian, E.D. (2008). A whey-protein supplement increases fat loss and spares lean muscle in obese subjects: a randomized human clinical study. Nutrition \& Metabolism, $5: 8$.

Grant, S., Hasler, T., Dvies, C., Aitchison, T.C., Wilson, J., \& Whittaker, A.A (2001). Comparison of anthropometric, strength, endurance and flexibility characteristics of female elite and recreational climbers and non-climbers. Journal of Sports Sciences, 19, 499-505.

Haff, G.G., Lehmkuhl, M.J., McCoy, L.B., \& Stone M.H. (2003). Carbohydrate supplementation and resistance training. Journal of Strength and Conditioning Research, 17(1), 187-196.

Hoffman, J.R., Ratamess, N.A., Kang, J., Falvo, M. J., \& Faigenbaum, A.D. (2006). Effect of protein intake of strength, body composition and endocrine changes in strength/power athletes. Journal of the International Society of Sports Nutrition, 3(2), 12-18

Hoffman, J.R., Ratamess, N.A., Tranchina, C.P., Rashti, S.L., Kang, J., \& Faigenbaum, A.D. (2009). Effect of proteinsupplement timing on strength, power, and body-composition changes in resistance-trained men. International Journal of Sport Nutrition and Exercise Metabolism, 19(2), 172-185.

Hopkins, W., Marshall, S., Batterham, A., \& Hanin, J. (2009). Progressive statistics for studies in sports medicine and exercise science. Medicine and Science and Sports and Exercise, 41(1), 3-13.

Hulmi, J.J., Lockwood, C.M., \& Stout, J.R. (2010). Effect of protein/essential amino acids and resistance training on skeletal muscle hypertrophy: A case for whey protein. Nutrition \& Metabolism, 17(7), 51-62.

Ignjatović, A., Stanković, R., Radovanović, D., Marković, Ž., \& Cvećka, J. (2009). Resistance training for youths. Facta Universitatis Series Physical Education and Sport, 7(2), 189-196.

Josse, A.R, Tang, J.E., Tarnopolsky, M.A. \& Phillips, S.M. (2009). Body composition and strength changes in women with milk and resistance exercise. Medicine and Science in Sports and Exercise, 42(6), 1122-1130.

Joy, J. M., Lowery, R. P., Wilson, J. M., Purpura, M., De Souza, E. O., Wilson, S. M., et al. (2013). The effects of 8 weeks of whey or rice protein supplementation on body composition and exercise performance. Nutrition Journal, 12(1), 86.

Kreamer, W.J., Ratamess, N., Fry, A.C., Triplett-McBride, T., Koziris, L.P., Bauer, J.A., et al. (2000). Influence of resistance training volume and periodization on phzsiological and performance adaptations in collegiate women tennis players. The American Journal of Sport Medicine, 28(5), 626-633.

Leiper, J.B., Aulin, K.P., \& Soderlund, K. (2000). Improved gastric emptying rate in humans of a unique glucose polymer with gel-forming properties. Scandinavian Journal of Gastroenterology, 35(11), 1143-1149.

Maksimović, D., Vukadinović, M., Rakonjac, D., Obradović, J., \& Barišić, V. (2016). Effects of heavy resistance training on morphological characteristics of young adults. Acta Kinesiologica, 10(1), 97-100.

Moore, D.R., Robinson, M.J., Fry, J.L., Tang, J.E., Glover, E.I., \& Wilkinson et al. (2009). Ingested protein dose response of muscle and albumin protein synthesis after resistance exercise in young men. The American Journal of Clinical Nutrition, 89(1), 161-168.

Miller, S.L., Tipton, K.D., Chinkes, D.L., Wolf, S.E., \& Wolfe, R.R. (2003). Independent and combined effects of amino acids and glucose after resistance exercise. Medicine \& Science in Sports and Exercise, 35(3), 449-455.

Nemet, D., Wolach, B., \& Eliakim, A. (2005). Proteins and amino acid supplementation in sports: Are they truly necessary? The Israel Medicine Association Journal, 7(5), 328-332.

Rasmussen, B.B., Tipton, K.D., Miller, S.L., Wolf, S.E. \& Wolfe, R.R. (2000). An oral essential amino acidcarbohydrate supplement enhances muscle protein anabolism after resistance exercise. Journal of Applied Physiology, 88(2), 386-392.

Rennie, M.J., Wackerhage, H., Spangenburg, E.E., \& Booth, F.W. (2004). Control of the size of the human muscle mass. Annual Review Physiology, 66, 799-828.

Schumacher, Y.O., Schmid A., König, D., \& Berg A. (2002). Effects of exercise on soluble transferrin receptor and other variables of the iron status. British. Journal of Sports Medicine, 36(3), 195-199.

Stephens, F.B., Roig, M., Armstrong, G., \& Greenhaff, P.L. (2008). Post-exercise ingestion of a unique, high molecular weight glucose polymer solution improves performance during a subsequent bout of cycling exercise. Journal of Sports Sciences, 26(2), 149-154. 
Tipton, K.D., Rasmussen B.R., Miller, S. L., Wolf S.E., Owens-Stovall S.K., Petrini, B.E., \& Wolfe, R.R. (2001). Timing of amino acid-carbohydrate ingestion alters anabolic response of muscle to resistance exercise. American Journal of Physiology, 281(2), 197-206.

Tipton, K.D., Elliot, T.A., Cree, M.G., Wolf, S.E., Sanford, A.P., \& Wolfe, R.R. (2004). Ingestion of casein and whey proteins result in muscle anabolism after resistance exercise. Medicine \& Science in Sports \& Exercise, 36(12), 2073-2081.

Vukadinović Jurišić M., Rakonjac, D., \& Obradović, J. (2017). Effects of carbohydrate supplementation in combination with resistance training on morphological characteristics. In: Z. Grgantov et al. (Eds.), Proceedings Book of the 6th International Scientific Conference „Contemporary Kinesiology“ (pp.83-92). Split: Faculty of Kinesiology

Westcott, W.L. (2012). Resistance training is medicine: effects of strength training on health. Current Sports Medicine Reports Journal, 11(4), 209-216.

Williams, M. (2005). Dietary supplements and sports performance: Amino Acids. Journal of the International Society of Sports Nutrition, 2(2), 63-67.

Willoughby, D.S, Stout, J.R, \& Wilborn, C.D. (2007). Effects of resistance training and protein plus amino acid supplementation on muscle anabolism, mass, and strength. Amino Acids, 32(4), 467-477.

Wolfe, R.R (2001). Effects of amino acid intake on anabolic processes. Canadian Journal of Applied Physiology, 26(1), 220-227.

\section{EFEKTI TRENINGA SA OPTEREĆENJEM U KOMBINACIJI SA VEJ PROTEINOM I UGLJENIM HIDRATIMA NA TELESNU KOMPOZICIJU I SNAGU KOD ADOLESCENATA}

Cilj ove studije bio je da se utvrde efekti vej poroteina i ugljenih hidrata tokom osam nedelja treninga sa opterećenjam na telesnu kompoziciju i snagu adolescenata. Petnaest adolescenata (uzrasta $21 \pm 5$ godina; telesne visine $178.63 \pm 4.1 \mathrm{~cm}$; telesne mase $81.73 \pm 4.97 \mathrm{~kg}$ ) randomizacijom su podeljeni u tri grupe: vej protein grupu (WP; $1 \mathrm{~g} / \mathrm{kg}$ odmah posle treninga sa opterećenjem; $n=5$ ), grupu koja je pila ugljene hidrate (CHO; $30 \mathrm{~g}$ tokom i $30 \mathrm{~g}$ odmah posle treninga sa opterećenjme; $n=5)$ i kontrolnu grupu $(K ; n=5)$. Ispitanici iz sve tri grupe primenjivali su 8 nedelja trening sa opterećenjem. Trening sa opterećenjem trajao je 8 nedelja, 4 puta nedeljno (90 min). Svi ispitanici bili su testirani na pojedine parametre telesne komopozicije: telena težina, bezmasna masa, masna masa, glikogen masa, mišićna masa, telesna voda, ekstracelularna voda i intracelularna voda. Takođe je procenjena snaga uz pomoć $1 R M$ (1 ponavljajućeg maksimuma) na benč presu, IRM čučanj, IRM za ramena i maksimalan broj zgibova. Podaci su obrađeni anovom za ponovljena merenja, a statistička značajnost bila je $p<0.05$. Rezultati pokazuju da se kod WP grupe ostvaruju bolji rezultati u bezmasnoj masi, mišićnoj masi i u povećanju 1RM čučnja nego kod CHO i K grupe $(p<0.05)$. Kod CHO grupe mogu se uočiti bolji rezultati u IRM benč presa, 1RM čučnja i kod 1RM potisku iznad ramena, kao i u smanjenju masne mase nego kod K grupe ( $p<0.05)$. Nalazi ove studije pokazuju da se kod mladih adolescenata koji konzumiraju vej protein tokom osam nedelja treninga sa operećenjem postižu bolji rezultati u telesnoj masi i snazi nego kod adolescenata koji su konzumirali ugljene hidrate.

Ključne reči: suplementacija, trening snage, uticaj, telesni sastav 